\title{
Multiple ring buffer untuk mengetahui aksesibilitas fasilitas kesehatan terhadap pola hidup sehat masyarakat kecamatan prambanan
}

\author{
Eka Septiyaningsih*, Muhammad Rizal Pahleviannur*, Nabila Kinthen*, Mulyani*, \\ Else Nungky Delisa Putri*, Alfi Okta Syahputra* \\ "Pendidikan Geografi, Fakultas Keguruan dan Ilmu Pendidikan Universitas \\ Muhammadiyah Surakarta
}

\begin{tabular}{l}
\hline INFO ARTIKEL \\
\hline Riwayat Artikel: \\
Dikirim: 11-7-2018 \\
Disetujui: $28-1-2019$ \\
Diterbitkan: $31-1-2019$ \\
\hline
\end{tabular}

Kata kunci:

aksesibilitas; fasilitas kesehatan; pola hidup sehat;

\begin{abstract}
ABSTRAK
Abstract: The development of a region is closely related to the availability of facilities and infrastructure, especially those used as drivers of the economy, education, and health. Good natural resources and human resources in a region will serve as a center of development, one of them is the development of accessibility of health service. The purpose of the research was to determine the effect of health facilities on a healthy lifestyle and to establish a good standard of healthy living in Prambanan Sub-district. The research method used is a quantitative and descriptive method, the data collected using the questionnaire research instrument. The population in this research is the whole plot of residential buildings which amounted to 20,943 buildings with a sample of 2,235 respondents. Respondent data which included in the sample will be input into a multiple ring buffer map to distinguish the healthy lifestyle of the peoples with accessibility criteria for $1.5 \mathrm{~km}$ residential area. The result of the research is known the healthy lifestyle of the peoples in Prambanan Sub-district can be distinguished with accessibility criteria of settlement area within $1.5 \mathrm{~km}$ and outside $1.5 \mathrm{~km}$. A healthy lifestyle is divided into 2 types, type 1 includes the benefits of drinking water, a good time to eat, waste and cleaning food. Type 2 includes cleaning up the living environment, draining the tub, washing hands with soap and sports. Peoples within the $1.5 \mathrm{~km}$ area are understood about a healthy lifestyle with a percentage of $60 \%$ and because they have better accessibility than peoples outside the $1.5 \mathrm{~km}$ area. Peoples who are not within the $1.5 \mathrm{~km}$ area are less understand about a healthy lifestyle with the percentage of $28 \%$ and because they have less accessibility than peoples within the 1.5 $\mathrm{km}$ area.
\end{abstract}

Abstrak: Perkembangan suatu wilayah sangat terkait dengan
ketersediaan sarana dan pra-sarana, khususnya yang digunakan
sebagai penggerak perekonomian, pendidikan, dan kesehatan.
Sumber daya alam dan sumber daya manusia yang baik di
suatu wilayah akan berfungsi sebagai pusat perkembangan,
salah satunya perkembangan aksesibilitas pelayanan
kesehatan. Tujuan penelitian untuk mengetahui pengaruh
fasilitas kesehatan terhadap pola hidup sehat dan membentuk
standar hidup sehat masyarakat yang baik di Kecamatan
Prambanan. Metode penelitian yang digunakan adalah metode
deskriptif kuantitatif, data dikumpulkan menggunakan 
Jurnal Pendidikan Geografi:

Kajian, Teori, dan Praktik dalam Bidang Pendidikan dan Ilmu Geografi

Tahun 24, Nomor 1, Jan 2019, Hal 42-51

instrumen penelitian berupa angket berisikan daftar pertanyaan
atau kuesioner. Populasi dalam penelitian ini adalah seluruh
persil bangunan pemukiman yang berjumlah 20.943 bangunan
dengan sampel sebanyak 2.235 responden. Data responden
yang termasuk ke dalam sampel akan di masukkan ke dalam
peta multiple ring buffer untuk dibedakan pola hidup sehat
masyarakat dengan kriteria aksesibilitas daerah permukiman
$1,5 \mathrm{~km}$. Hasil penelitian diketahui pola hidup sehat masyarakat
Kecamatan Prambanan dapat dibedakan dengan kriteria
aksesibilitas daerah pemukiman dalam $1,5 \mathrm{~km}$ dan di luar 1,5
km. Pola hidup sehat dibedakan menjadi dua tipe, tipe yang
pertama meliputi manfaat minum air putih, waktu makan yang
baik, membuang sampah, dan kebersihan makanan. Tipe yang
kedua meliputi lingkungan tempat tinggal, menguras bak
mandi, mencuci tangan dengan sabun, dan olahraga.
Masyarakat yang masuk dalam wilayah 1,5 km paham akan
pola hidup sehat dengan persentase $60 \%$ dan karena mereka
memiliki aksesibilitas keterjangkauan yang lebih baik daripada
masyarakat di luar wilayah 1,5 km. Masyarakat yang tidak
masuk.

Alamat Korespondensi:

Eka Septiyaningsih

Pendidikan Geografi

Universitas Muhammadiyah Surakarta

J1. A. Yani Tromol Pos 1 Pabelan Surakarta, Pabelan-57169 Telp:0291-717417 E-

mail: ekaseptiyaningsih4@gmail.com

\section{PENDAHULUAN}

Kecamatan Prambanan merupakan wilayah yang berbatasan dengan Daerah Istimewa Yogyakarta (DIY), terletak di 1100.30' - 1100.45' Bujur Timur, 7.30 - 7.45口 Bujur Selatan, memiliki luasan 24,43 $\mathrm{Km}^{2}$ dan memiliki 16 desa. Terdapat dua kecamatan dengan nama prambanan yaitu Kecamatan Prambanan dalam wilayah Kabupaten Klaten Provinsi Jawa Tengah dan Kecamatan Prambanan dalam wilayah Kabupaten Sleman Provinsi DIY. Berdasarkan data dari BPS Kabupaten Klaten, jumlah penduduk Kecamatan Prambanan Tahun 2017 sebesar 49.533 jiwa, dengan luas wilayah 24,43 $\mathrm{Km}^{2}$. Perkembangan suatu wilayah sangat terkait dengan ketersediaan sarana dan prasarana wilayah, khususnya sarana perekonomian, pendidikan, dan kesehatan. Sumber Daya Alam dan Sumber Daya Manusia yang baik disuatu wilayah akan berfungsi sebagai pusat perkembangan, salah satunya perkembangan pelayanan kesehatan.

Fasilitas kesehatan merupakan fasilitas pelayanan kesehatan yang digunakan untuk menyelenggarakan upaya pelayanan kesehatan. Fasilitas kesehatan dapat berupa rumah sakit, puskesmas, dan klinik. Todoro (2002) dalam (Pohan, 2013)menyatakan bahwa pada dasarnya kesehatan merupakan salah satu aspek yang menentukan tinggi rendahnya standar hidup seseorang. Oleh karena itu, status kesehatan dengan kondisi relatif baik dibutuhkan oleh manusia untuk menopang semua aktivitas hidupnya, maka untuk mencapai kondisi kesehatan dengan kriteria baik tersebut, dibutuhkan infrastruktur atau fasilitas kesehatan yang baik pula. Infrastruktur kesehatan yang dibutuhkan terbagi kedalam infrastruktur kesehatan fisik dan infrastruktur nonfisik. Infrastruktur fisik kesehatan meliputi bangunan rumah sakit, puskesmas, klinik, apotek, jalan raya, rel kereta api, bandara dan sebagiannya.

Pembangunan infrastruktur mempengaruhi aksesibilitas terhadap fasilitas kesehatan. Hal ini bisa terlihat penduduk yang tinggal dipedesaan memiliki kesehatan yang 
rendah karena jauh dari fasilitas kesehatan yang dipengaruhi oleh aksesibilitas yang susah dijangkau, sedangkan penduduk yang berada dikota memiliki kesehatan yang tinggi karena memiliki aksesibilitas yang mudah dijangkau. Dalam perencanaan permukiman, banyak factor yang dapat diukur secara cepat dan akurat menggunakan alat bantu Sistem Informasi Geografis (SIG). Kemampuannya yang dapat memadukan data gambar (peta) dengan datadata tabulasi (angka dan teks), memungkinkan SIG membuat Analisa dan prediksi mengenai fenomena-fenomena yang ingin diketahui sebagai informasi perencanaan. Salah satu faktor yang dapat diukur adalah fenomena-fenomena yang dibaca oleh fasilitas buffer atau buffering (Aqli, 2010). Fenomena yang bersifat cakupan atau radius, contohnya keberadaan fasilitas kesehatan bisa diketahui melalui fitur buffer tersebut. Mengenai tersediannya tenaga pelayanan kesehatan merupakan hal yang harus dipenuhi dalam mewujudkan pembangunan di bidang kesehatan. Aksesibilitas pelayanan kesehatan perlu dilakukan pada tingkat kabupaten/kota, agar dapat memberikan gambaran yang operasional.

Semua penduduk tidak bisa dikatakan dapat menjangkaunya pelayanan kesehatan sevcara meyeluruh dikarenakan luas wilayah yang cukup luas, sarana perhubungan yang tidak memadai, dan kepadatan penduduk yang semakin meningkat. Agar, jangkauan pelayanan kesehatan lebih merata dan meluas, puskesmas perlu ditunjang dengan puskesmas pembantu, penempatan bidan di desa-desa yang belum terjangkau oleh pelayanan yang ada, dan puskesmas keliling. Disamping itu penggerakan peran serta masyarakat untuk mengelola posyandu dan membina 'Dasa Wisma' akan dapat menunjang jangkauan pelayanan kesehatan (Depkes, 1992)

Menurut Sheridan (1992) pola hidup sehat merupakan aspek perilaku manusia yang berkaitan dengan kebutuhan. Dalam perkembangan teknologi, untuk memenuhi pola hidup sehat, masyarakat perlu mengutamakan kecepatan dalam hal mobilitas, efisiensi, dan berorientasi pada target. Sehingga untuk memenuhi sebuah tuntutan pola hidup sehat perlu mengembangkan suatu gaya hidup sehat sesuai kaidah perilaku hidup sehat.

Menurut World Health Organization pada Tahun 1948, menyatakan bahwa kesehatan adalah suatu keadaan mental, fisik, kesejahteraan sosial, dan bukan hanya pada ketiadaan penyakit kepada seluruh manusia. Pada era modern seperti sekarang ini banyak orang yang tidak menghiraukan kesehatan tubuhnya. Aksesibilitas fasilitas kesehatan juga berpengaruh dalam mendukung gerakan pola hidup sehat. Adapun tujuan atau pengaruh dari suatu fasilitas kesehatan yaitu dapat menyediakan kebutuhan untuk pemenuhan kesehatan masyarakat di Kecamatan Prambanan.

Pengaruh pola hidup sehat yang berada di Kecamatan Prambanan disebabkan oleh adanya faktor keterjangkauan fasilitas kesehatan yang tersedia. Kebiasaan pola hidup yang diterapkan dan budaya dari masyarakat dapat mempengaruhi kondisi kesehatan dari masyarakat. Pengembangan pola hidup sehat yang terdiri dari pola makan, olahraga, waktu istirahat, gaya hidup, dan sanitasi merupakan faktor penting. Penelitian ini direncanakan untuk mengetahui pengaruh aksesibilitas fasilitas kesehatan yang dapat mempengaruhi pola hidup sehat masyarakat di Kecamatan Prambanan.

Penelitian ini dilakukan di Kecamatan Prambanan karena berdasarkan karakteristik Kecamatan Prambanan yang berbeda dari daerah-daerah misalnya topografi daerah, masyarakat, dan lingkungannya, sehingga perlu adanya pengkajian terhadap standar pola hidup sehat di kecamatan prambanan. Tujuan Penelitian untuk mengetahui pengaruh fasilitas kesehatan terhadap pola hidup sehat dan membentuk standar hidup sehat masyarakat yang baik di Kecamatan Prambanan. Berdasarkan uraian diatas peneliti menyusun judul "Multiple Ring Buffer untuk Mengetahui Aksesibilitas Fasilitas Kesehatan dan Pola Hidup Sehat Masyarakat Kecamatan Prambanan". 
Jurnal Pendidikan Geografi:

Kajian, Teori, dan Praktik dalam Bidang Pendidikan dan Ilmu Geografi

Tahun 24, Nomor 1, Jan 2019, Hal 42-51

METODE

Desain penelitian yang digunakan dalam penelitian ini adalah deskriptif dengan pendekatan kuantitatif.

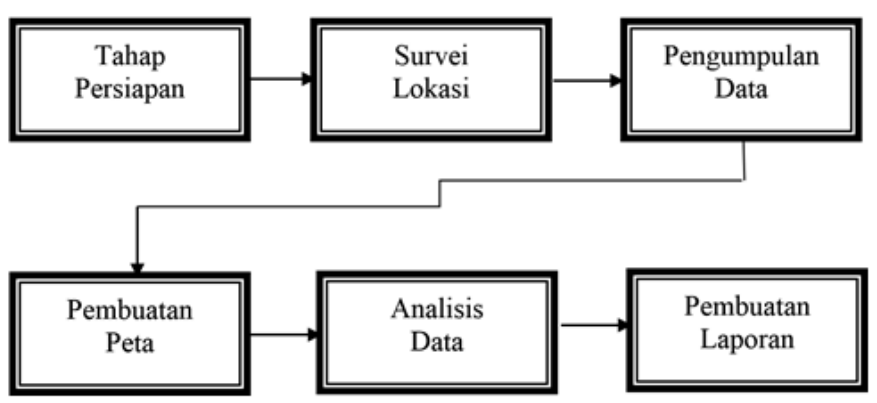

Gambar 1. Diagram Alir Prosedur Penelitian

Gambar 1 menjelaskan tentang diagram alir prosedur penelitian. Penelitian dilaksanakan pada bulan Maret hingga Juni 2018 dengan beberapa tahapan penelitian, tahap peneliti dimulai dengan tahap persiapan yaitu digitasi persil permukiman 16 desa di Kecamatan Prambanan dan menyiapkan instrumen penelitian berupa angket yang berisikan daftar pertanyaan kuisioner, survei lokasi merupakan tahap kedua penelitian untuk menentukan bahwa digitasi persil merupakan persil bangunan untuk kategori tempat tinggal manusia. Tahap ketiga adalah pengumpulan data yang dilaksanakan selama 4 hari pada tanggal 29 Maret-02 April 2018 dengan menggunakan instrumen penelitian berupa angket yang berisikan daftar pertanyaan atau kuisioner. Setelah mendapatkan titik koordinat kawasan penelitian dan titik koordinat fasilitas kesehatan, selanjutnya adalah pembuatan peta multiple ring buffer. Selanjutnya, analisis data dapat dilakukan setelah semua data yang dibutuhkan terkumpul. Kemudian, tahap pembuatan laporan dilakukan guna melaporkan hasil penelitian. Populasi dalam penelitian ini sebanyak 20.943 responden.

Penentuan ukuran sampel menggunakan rumus slovin menggunakan toleransi kesalahan $2 \%$ dengan rumus sebagai berikut:

$$
\begin{aligned}
& n=\frac{N}{1+N e^{2}} \\
& \text { Keterangan : } \\
& \mathrm{n}=\text { ukuran sampel, } \\
& \mathrm{N}=\text { ukuran populasi } \\
& \mathrm{e}=\text { taraf kesalahan }
\end{aligned}
$$

Berdasarkan rumus tersebut maka perhitungan sampel adalah sebagai berikut:

$$
\begin{gathered}
n=\frac{20943}{1+20943(0,02)^{2}} \\
=\frac{20943}{1+20943(0,0004)}=\frac{20943}{9,3772} \\
=2.233,3959=2.234 \text { responden }
\end{gathered}
$$

Teknik sampling yang digunakan dalam penelitian ini adalah Simple Random Sampling (Yunus, 2010) dengan menggunakan tabel acak di software excel untuk penentuan sampel, setelah di acak di Software Excel diinput ke dalam Software ArcMap untuk memperoleh gambaran sampel mana yang masuk dalam multiple ring buffer kriteria aksesibilitas daerah permukiman 1,5 km dengan sampel yang tidak masuk. Sampel yang 
Jurnal Pendidikan Geografi:

Kajian, Teori, dan Praktik dalam Bidang Pendidikan dan Ilmu Geografi

Tahun 24, Nomor 1, Jan 2019, Hal 42-51

masuk dalam kriteria aksesibilitas daerah permukiman $1,5 \mathrm{~km}$ meliputi 908 sampel, sedangkan sampel yang tidak termasuk 1031 sampel. Sampel yang masuk dalam kriteria aksesibilitas $1,5 \mathrm{~km}$ akan dibandingkan pola hidup sehat masyarakatnya dengan yang tidak masuk dalam kriteria aksesibilitas 1,5 km.

\section{HASIL DAN PEMBAHASAN}

Hasil olah data penelitian dapat dihasilkan dari analisis kesehatan atau pola hidup sehat dan kondisi sosial ekonomi masyarakat Kecamatan Prambanan.

\section{Analisis Pola Hidup Sehat}

Analisis pengetahuan tentang pola hidup sehat terbagi menjadi dua tipe pengukuran. Tipe satu meliputi pengetahuan tentang manfaat minum air putih, waktu makan yang baik, membuang sampah, dan kebersihan makanan. Tipe dua meliputi pengetahuan tentang membersihkan lingkungan tempat tinggal, menguras bak mandi, mencuci tangan dengan sabun, dan olahraga rutin. Pembagian tipe ini akan mempermudah dalam analisis data dan pengolongan pola hidup sehat masyarakat yang masuk dalam kriteria aksesibilitas daerah permukiman $1,5 \mathrm{~km}$ dan yang tidak masuk. Penjelasan ini dapat dinyatakan dengan grafik dibawah ini:

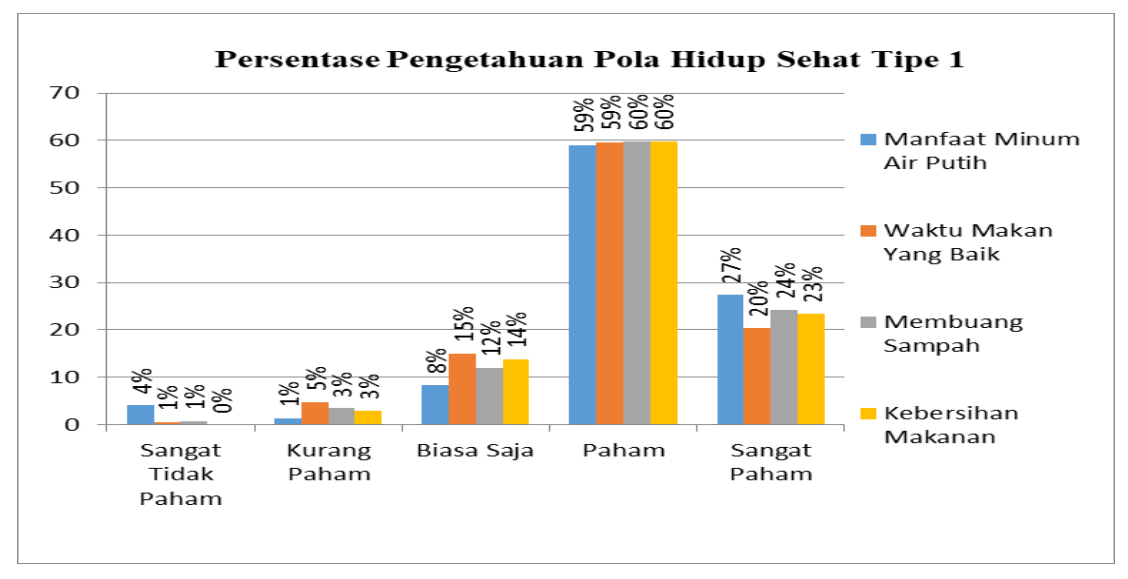

Gambar 2. Presentase Pengetahuan Pola Hidup Sehat Tipe 1 Masuk 1,5 Km

Gambar 2 menjelaskan tentang grafik persentase pengetahuan pola hidup sehat tipe satu masyarakat Kecamatan Prambanan mempunyai aksesibilitas yang baik yaitu $1,5 \mathrm{~km}$. Grafik pengetahuan pola hidup sehat dapat dilihat dari segi pengetahuan manfaat minum air putih, waktu makan yang baik, membuang sampah, dan kebersihan makanan. Dilihat dari grafik tersebut, persentase tertinggi sebesar 59\% untuk indikator manfaat minum air putih, $59 \%$ untuk indikator waktu makan yang baik, $60 \%$ untuk indikator membuang sampah, dan $60 \%$ untuk indikator kebersihan makanan. Hal tersebut memiliki kriteria paham. Sedangkan, persentase terendah yaitu $4 \%$ untuk indikator manfaat minum air putih, $1 \%$ untuk indikator waktu makan yang baik, $1 \%$ untuk indikator membuang sampah, dan $0 \%$ untuk indikator kebersihan makanan. Hal tersebut memiliki kriteria sangat tidak paham. Kesimpulan pada grafik kesehatan tersebut, masyarakat paham manfaat minum air putih, waktu makan yang baik, membuang sampah dan kebersihan makan. 
Jurnal Pendidikan Geografi:

Kajian, Teori, dan Praktik dalam Bidang Pendidikan dan Ilmu Geografi

Tahun 24, Nomor 1, Jan 2019, Hal 42-51

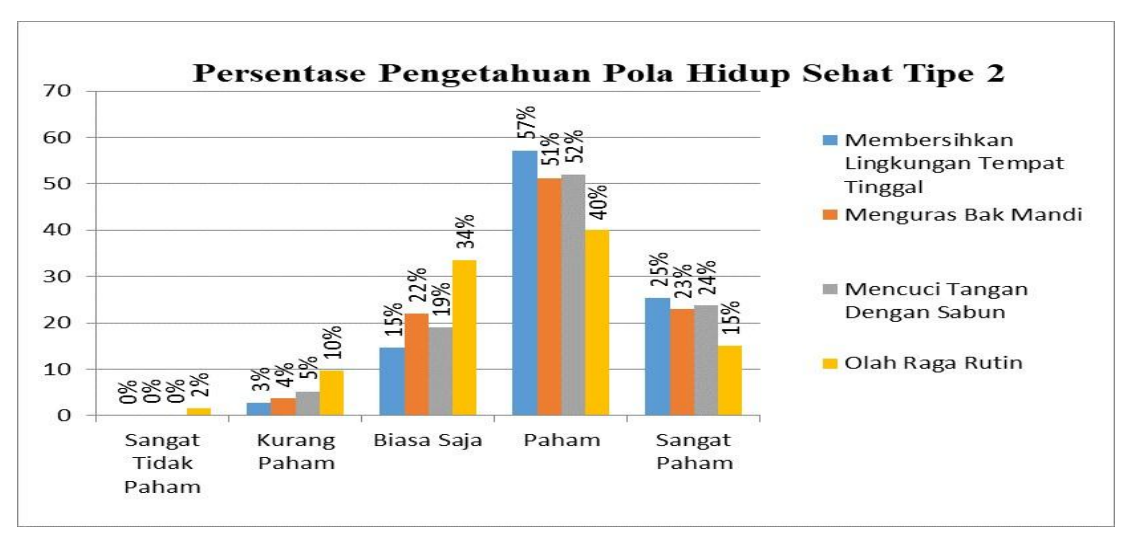

Gambar 3. Presentase Pengetahuan Pola Hidup Sehat Tipe 2 Masuk 1,5 Km

Gambar 3 menjelaskan tentang grafik persentase pengetahuan pola hidup sehat tipe dua masyarakat Kecamatan Prambanan mempunyai aksesibilitas yang baik yaitu 1,5 km. Kesehatan dapat dilihat dari segi membersihkan lingkungan tempat tinggal, menguras bak mandi, mencuci tangan dengan sabun, dan olahraga rutin. Dilihat dari grafik tersebut, persentase tertinggi sebesar 57\% untuk indikator membersihkan lingkungan tempat tinggal, $51 \%$ untuk indikator menguras bak mandi, 52\% untuk indikator mencuci tangan dengan sabun, dan $40 \%$ untuk indikator olah raga rutin. Hal tersebut memiliki kriteria paham. Sedangkan, persentase terendah yaitu $0 \%$ untuk membersihkan lingkungan tempat tinggal, $0 \%$ untuk indikator menguras bak mandi, $0 \%$ untuk indikator mencuci tangan dengan sabun, dan $2 \%$ indikator untuk olah raga rutin. Hal tersebut memiliki kriteria sangat tidak paham. Kesimpulan pada grafik kesehatan tersebut, masyarakat paham dalam hal membersihkan lingkungan tempat tinggal, menguras bak mandi, mencuci tangan dengan sabun dan olahraga rutin.

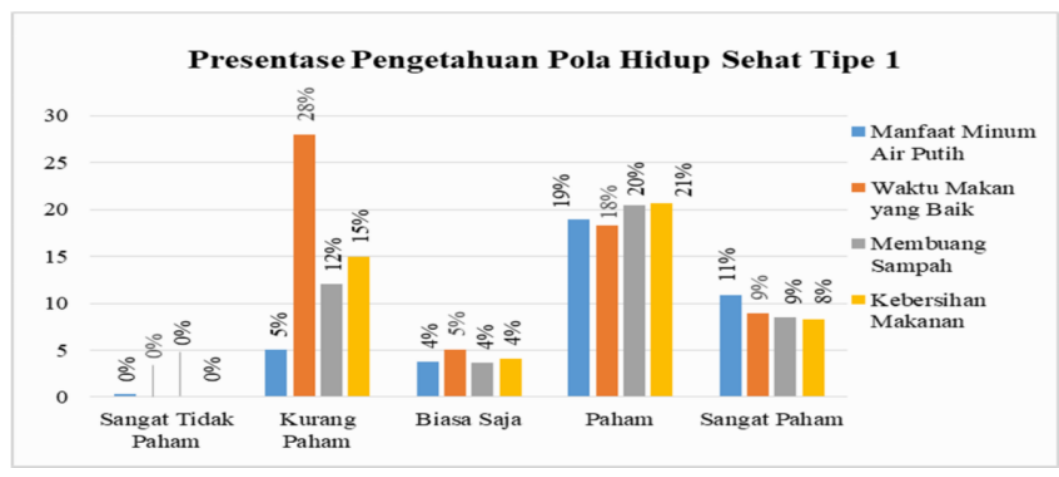

Gambar 4. Presentase Pengetahuan Pola Hidup Sehat Tipe 1 di luar 1,5 Km

Gambar 4 menjelaskan tentang grafik persentase pengetahuan pola hidup sehat tipe satu masyarakat Kecamatan Prambanan mempunyai aksesibilitas kurang baik atau lebih dari $1,5 \mathrm{~km}$. Grafik pengetahuan pola hidup sehat dapat dilihat dari segi pengetahuan manfaat minum air putih, waktu makan yang baik, membuang sampah, dan kebersihan makanan. Dilihat dari grafik tersebut, persentase tertinggi sebesar 19\% untuk indikator manfaat minum air putih dengan kriteria paham, $28 \%$ untuk indikator waktu makan yang baik dengan kriteria 
Jurnal Pendidikan Geografi:

Kajian, Teori, dan Praktik dalam Bidang Pendidikan dan Ilmu Geografi

Tahun 24, Nomor 1, Jan 2019, Hal 42-51

kurang paham, $20 \%$ untuk indikator membuang sampah dengan kriteria paham, dan $21 \%$ untuk indikator kebersihan makan dengan kriteria paham. Sedangkan, persentase terendah yaitu $0 \%$ untuk semua indikator dengan kriteria sangat tidak paham. Kesimpulan pada grafik kesehatan tersebut, masyarakat kurang paham waktu makan yang baik.

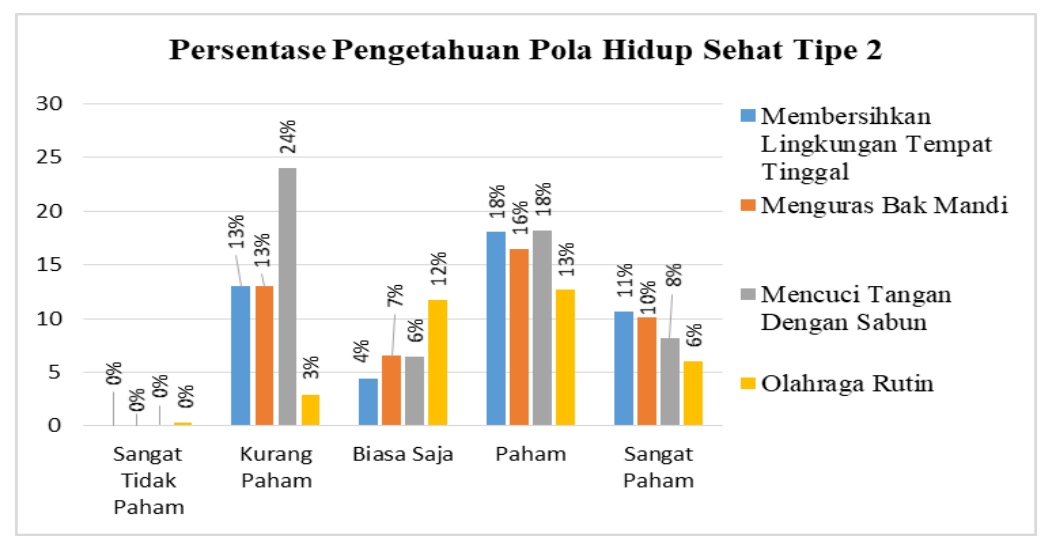

Gambar 5. Presentase Pengetahuan Pola Hidup Sehat Tipe 2 di luar 1,5 Km

Gambar 5 menjelaskan tentang grafik persentase pengetahuan pola hidup sehat tipe satu masyarakat Kecamatan Prambanan mempunyai aksesibilitas kurang baik atau lebih dari 1,5 km. Grafik kesehatan dapat dilihat dari segi membersihkan lingkungan tempat tinggal, menguras bak mandi, mencuci tangan dengan sabun, dan olahraga rutin. Dilihat dari grafik tersebut, persentase tertinggi sebesar $18 \%$ untuk indikator membersihkan lingkungan tempat tinggal dengan kriteria paham, $16 \%$ untuk indikator menguras bak mandi dengan kriteria paham, 24\% untuk indikator mencuci tangan dengan sabun termasuk dalam kriteria kurang paham, dan $13 \%$ untuk indikator olah raga dengan kriteria paham. Kesimpulan bahwa pada grafik kesehatan tersebut, mencuci tangan dengan sabun memiliki pengaruh yang lebih daripada indikator yang lain.

\section{Analisis Perubahan Kondisi Sosial Ekonomi}

Analisis perubahan kondisi sosial ekonomi dilihat dari jaminan kesehatan, fasilitas transportasi, waktu istirahat, kemampuan bekerja, kondisi tempat tinggal, dan akses pelayanan kesehatan.

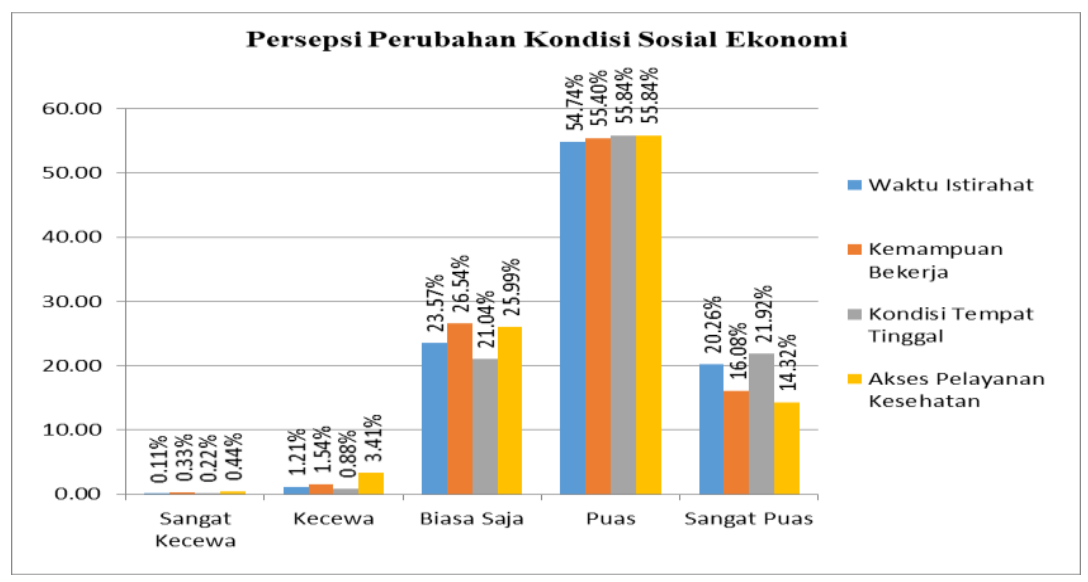

Gambar 6. Grafik Persepsi Perubahan Kondisi Sosial Ekonomi Masuk 1.5 Km 
Gambar 6 menjelaskan tentang grafik perubahan kondisi sosial ekonomi masyarakat di Kecamatan Prambanan dengan kriteria aksesibilitas 1,5 km. Perubahan kondisi sosial ekonomi dapat dilihat dari segi waktu istirahat, kemampuan bekerja, kondisi tempat tinggal, dan akses pelayanan kesehatan. Dilihat dari grafik tersebut, persentase tertinggi sebesar $54.74 \%$ untuk indikator waktu istirahat, $55.40 \%$ untuk indikator kemampuan bekerja, 55.84\% untuk indikator kondisi tempat tinggal, dan $55.84 \%$ untuk indikator akses pelayanan kesehatan. Hal tersebut memiliki kriteria puas. Sedangkan, persentase terendah yaitu $0.11 \%$ untuk indikator waktu istirahat, $0.33 \%$ untuk indikator kemampuan bekerja, $0.22 \%$ untuk indikator kondisi tempat tinggal, dan $0.44 \%$ untuk indikator akses pelayanan kesehatan. Hal tersebut memiliki kriteria sangat kecewa, sehingga dapat disimpulkan bahwa pada grafik perubahan kondisi sosial ekonomi, waktu istirahat, dan kemampuan bekerja memiliki pengaruh lebih dibandingkan dengan indikator yang lain.

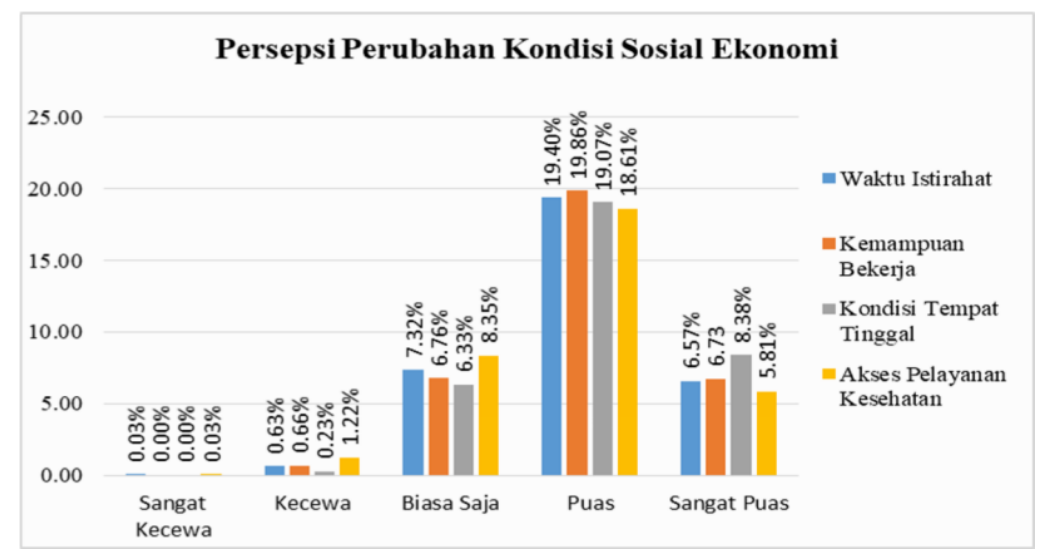

Gambar 7. Grafik Persepsi Perubahan Kondisi Sosial Ekonomi di Luar 1.5 Km

Gambar 7 menjelaskan tentang grafik perubahan kondisi sosial ekonomi masyarakat di Kecamatan Prambanan dengan kriteria jauh dari 1,5 km. Perubahan kondisi sosial ekonomi yang terletak di Kecamatan Prambanan, dapat dilihat dari segi waktu istirahat, kemampuan bekerja, kondisi tempat tinggal, dan akses pelayanan kesehatan. Dilihat dari grafik tersebut, persentase tertinggi sebesar $19.40 \%$ untuk indikator waktu istirahat, $19.86 \%$ untuk indikator kemampuan bekerja, $19.07 \%$ untuk indikator kondisi tempat tinggal, dan $18.61 \%$ untuk indikator akses pelayanan kesehatan. Hal tersebut memiliki kriteria puas. Sedangkan, persentase terendah yaitu $0.03 \%$ untuk indikator waktu istirahat, $0.00 \%$ untuk indikator kemampuan bekerja, $0.00 \%$ untuk indikator kondisi tempat tinggal, dan $0.03 \%$ indikator untuk akses pelayanan kesehatan. Hal tersebut memiliki kriteria sangat kecewa, sehingga dapat disimpulkan bahwa pada grafik perubahan kondisi sosial ekonomi, waktu istirahat dan kemampuan bekerja memiliki pengaruh lebih dibandingkan dengan indikator yang lain.

\section{KESIMPULAN}

Hasil penelitian diketahui pola hidup sehat masyarakat Kecamatan Prambanan dapat dibedakan dengan kriteria aksesibilitas daerah permukiman dalam 1,5 km dan di luar $1,5 \mathrm{~km}$. Pola hidup sehat masyarakat dapat dianalisis menggunkan data kesehatan dan kondisi sosial ekonomi masyarakat. Kesehatan meliputi pola hidup sehat yang dibedakan menjadi dua tipe, tipe satu meliputi manfaat minum air putih, waktu makan yang baik, membuang sampah dan kebersihan makanan. Tipe dua meliputi membersihkan lingkungan tempat tinggal, menguras bak mandi, mencuci tangan dengan sabun dan olahraga. 
Masyarakat yang masuk dalam wilayah $1,5 \mathrm{~km}$ dengan tipe satu dan tipe dua paham mengenai pola hidup sehat yang digambarkan dengan persentase tertinggi $60 \%$ untuk tipe satu dan 57\% untuk tipe dua. Masyarakat yang memiliki aksesibilitas lebih dari $1,5 \mathrm{~km}$ pada tipe satu dan tipe dua kurang paham mengenai pola hidup sehat yang memiliki persentase tertinggi sebesar $28 \%$ untuk tipe satu dan $24 \%$ untuk tipe dua.

Perubahan kondisi sosial ekonomi masyarakat yang memiliki aksesibilitas $1,5 \mathrm{~km}$ dengan persentase $60-80 \%$ dengan kriteria sama baik pada jaminan kesehatan dan fasilitas transportasi, puas terhadap waktu istirahat, kemampuan bekerja, kondisi tempat tinggal, dan akses pelayanan kesehatan yang digambarkan dengan persentase sebesar $60 \%$ puas, sedangkan masyarakat di luar aksesibilitas $1,5 \mathrm{~km}$ juga memiliki kriteria sama baik tetapi hanya memiliki persentase $18-20 \%$ untuk jaminan kesehatan dan fasilitas transportasi. Waktu istirahat, kemampuan bekerja, kondisi tempat tinggal dan akses pelayanan kesehatan memiliki kriteria puas hanya dengan 18-19\%.

Kesimpulan dari penelitian ini bahwa masyarakat Kecamatan Prambanan yang memiliki aksesibilitas $1,5 \mathrm{~km}$ paham mengenai pola hidup sehat, sedangkan masyarakat di luar aksesibilitas $1,5 \mathrm{~km}$ kurang paham tentang pola hidup sehat. Analisis ini dapat dilihat dari analisis kesehatan dan perubahan sosial ekonomi masyarakat Kecamatan Prambanan.

\section{DAFTAR RUJUKAN}

Arikunto, S. (2002). Prosedur penelitian suatu pendekatan praktek. Jakarta: PT. Rineka Cipta.

Aqli, W. (2010). Analisa buffer dalam sistem informasi geografis untuk perencanaan ruang kawasan. Inersia, 192-201.

Azwar, A. (2010). Pengantar administrasi kesehatan. Tangerang: Binarupa Aksara.

Ekowarni, E. (2001). Pola perilaku sehat dan model pelayanan kesehatan remaja. Jurnal Psikologi, 97-104.

Eryando, T. (2006). Aksesibilitas kesehatan maternal di Kabupaten Tangerang. Jurnal, 7683.

Kartono, K. (2001). Patologi sosial jilid I. Jakarta: Raja Grafindo Persada.

Magribi, L. o., \& Suhardjo, A. (2004). Aksebilitas dan pengaruhnya terhadap pembangunan di perdesaan: konsep model sustainable accessibilty pada kawasan pedesaan di provinsi sulawesi tenggara. Jurnal Transportasi, 149-160.

Meisa, Y. (2012). Permintaan (demand) dalam yankes.

Nara, A. (2014). Hubungan pengetahuan, sikap, akses pelayanan kesehatan, jumlah sumber informasi dan dukungan keluarga dengan pemanfaatan fasilitas persalinan yang memadai oleh ibu bersalin di puskesmas kawangu Kabupaten Sumba Timur. Skripsi.

Notoatmojo. (1993). Ilmu kesehatan masyarakat prinsip-prinsip dasar. Jakarta: PT. Rineka Cipta.

Pohan, I. S. (2004). Jaminan mutu pelayanan kesehatan: Dasar-dasar pengertian dan penerapan. Jakarta: EGC.

Pohan, M., \& Halim, R. (2013). Analisis ketersediaan infrastruktur kesehatan dan aksebilitas terhadap pembangunan kesehatan penduduk di Provinsi Sumatra Utara. Jurnal Ekonomi, 77-91.

Puskesmas, B. P. (1991/1992). Pedoman kerja puskesmas jilid I. Surakarta: Departemen Kesehatan Surakarta.

Sugiyono. (2017). Metode penelitian kuantitatif, kualitatif, dan R\&D. Bandung: ALFABETA.

Suharjana. (2012). Kebiasaan berperilaku hidup sehat dan nilai-nilai pendidikan karakter. Jurnal Pendidikan Karakter, 189-201. 
Jurnal Pendidikan Geografi:

Kajian, Teori, dan Praktik dalam Bidang Pendidikan dan Ilmu Geografi

Tahun 24, Nomor 1, Jan 2019, Hal 42-51

Suoth, M., Bidjuni, H., \& T. Malara, R. (2014). Hubungan gaya hidup dengan kejadian hipertensi di Puskesmas Kolongan Kecamatan Kalawat Kabupaten Minahasa Utara. ejurnal Keperawatan, 1-10.

Suthanaya, P. A. (2009). Analisis aksesibilitas penumpang angkutan umum menuju pusat Kota Denpasar di Provinsi Bali. Jurnal.

Wahyuni, N. S. (2012). Faktor-faktor yang berhubungan dengan pemanfaatan pelayanan kesehatan di Puskesmas Sumber Rejo Kota Balikpapan Provinsi Kalimantan Timur Tahun 2012. 1-64.

Winardi, J. (2002). Motivasi dan pemotivasian dalam manajemen. Jakarta: Raja Persada Grafindo.

Wulansari, I. R., Suprayogi, A., \& Nugraha, A. L. (2015). Pembuatan aplikasi sebaran lokasi fasilitas kesehatan penerima bpjs kesehatan di Kota Semarang Berbasis Android. Jurnal Geodesi Undip, 240-247.

Yunus, H. S. (2010). Metodologi Penelitian Wilayah Kontemporer. Yogyakarta: Pustaka Pelajar. 